\title{
Burnout Syndrome prevalence among nursing technicians of an Adult Intensive Care Unit
}

\author{
Prevalência de esgotamento profissional em técnicos em enfermagem de uma unidade de Terapia Intensiva Adulto
}

Prevalencia de Síndrome de Burnout em técnicos em enfermería de una Unidad de Terapia Intensiva Adulto

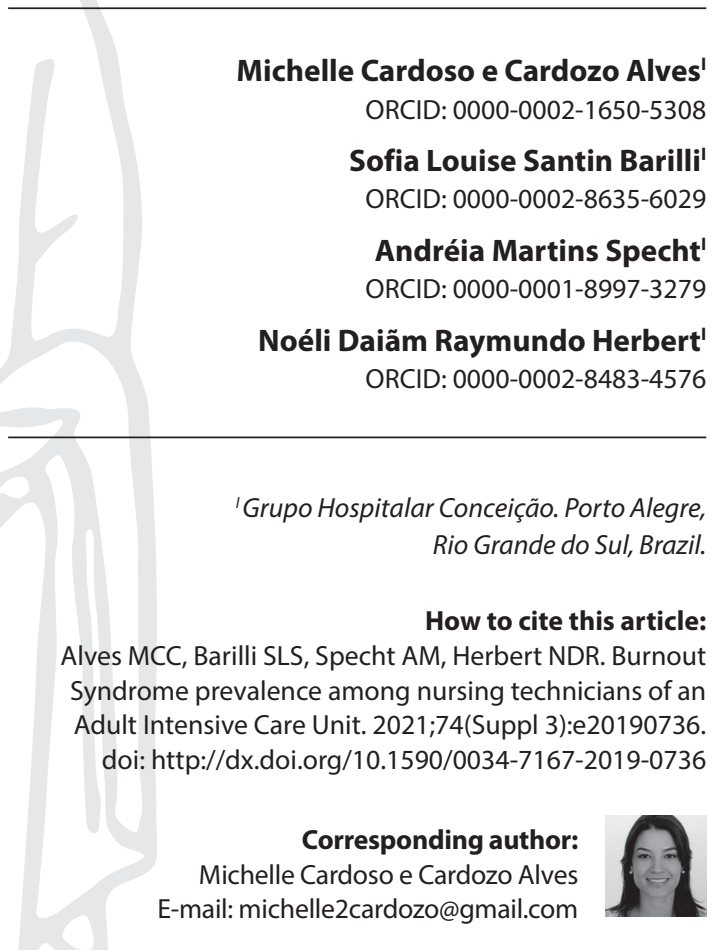

EDITOR IN CHIEF: Dulce Barbosa ASSOCIATE EDITOR: Andrea Bernardes

Submission: 01-22-2020 Approval: 09-20-2020

\begin{abstract}
Objective: to verify Burnout Syndrome prevalence among nursing technicians of an adult Intensive Care Unit and associate prevalence with sociodemographic and clinical data. Method: a cross-sectional study carried out in an adult Intensive Care Unit of a large public hospital in southern Brazil, between March and April/2018. Prevalence was assessed using the Maslach Burnout Inventory. Results: 122 nursing technicians participated (aged 39 \pm 2.5 years), $76 \%$ being women. Burnout Syndrome prevalence was $19.7 \%$ and $62.9 \%$. There was a significant association between Burnout Syndrome and depression $(p=0.004)$, as well as Burnout Syndrome and comorbidities ( $p=0.033$ ), when less conservative criteria were adopted. Conclusion: the findings are relevant to professionals in this area and may contribute to adopting strategies to combat Burnout Syndrome.

Descriptors: Burnout, Professional; Occupational Health; Intensive Care Units; Nursing, Staff; Nursing.
\end{abstract}

\section{RESUMO}

Objetivo: verificar a prevalência de esgotamento profissional (Síndrome de Burnout) em técnicos em enfermagem de uma Unidade de Terapia Intensiva adulto e associar a prevalência a dados sociodemográficos e clínicos. Método: estudo transversal, desenvolvido em Unidade de Terapia Intensiva adulto de hospital público de grande porte do Sul do Brasil, entre março e abril de 2018. A prevalência foi avaliada com o Maslach Burnout Inventory. Resultados: participaram 122 técnicos em enfermagem (idade $39 \pm 2,5$ anos), sendo $76 \%$ mulheres. As prevalências de Síndrome de Burnout foram 19,7\% e 62,9\%. Houve associação significativa entre Síndrome de Burnout e depressão $(p=0,004)$, assim como Síndrome de Burnout e comorbidades $(p=0,033)$, quando adotado critério menos conservador. Conclusão: os achados são relevantes para os profissionais desta área, podendo contribuir para adoção de estratégias de combate à Síndrome de Burnout.

Descritores: Esgotamento Profissional; Saúde do Trabalhador; Unidade de Terapia Intensiva; Equipe de Enfermagem; Enfermagem.

\section{RESUMEN}

Objetivo: verificar laprevalencia de agotamiento profesional (Síndrome de Burnout) en técnicos de enfermería de una Unidad de Cuidados Intensivos de adultos y asociar la prevalencia con datos sociodemográficos y clínicos. Método: estudio transversal, desarrollado en una unidad de cuidados intensivos para adultos de un gran hospital público delsur de Brasil, entre marzo y abril de 2018. La prevalencia se evaluó mediante el Maslach Burnout Inventory. Resultados: participaron 122 técnicos de enfermería (edad 39 $\pm 2,5$ años), de los cuales $76 \%$ eran mujeres. La prevalencia del síndrome de Burnout fue del $19,7 \%$ y del $62,9 \%$. Hubo asociación significativa entre Síndrome de Burnout y depresión $(p=0,004)$, así como Síndrome de Burnout y comorbilidades $(p=0,033)$, cuando se adoptó un criterio menos conservador. Conclusión: los hallazgos son relevantes para los profesionales de esta área y pueden contribuir a laadopción de estrategias para combatir el Síndrome de Burnout. Descriptores: Agotamiento Profesional; Salud Laboral; Unidades de Cuidados Intensivos; Grupo de Enfermeria; Enfermeria. 


\section{INTRODUCTION}

Intensive Care Units (ICUs) are specialized units that serve severely affected patients daily. Patients' suffering and death, work overload, complexity of actions, lack of human and material resources, performance of high-risk procedures, excessive noise, closed environment and artificial lighting, among others, are factors that generate stress and fatigue in workers of these units ${ }^{(1-4)}$.

Considering that there is a significant relationship between Burnout Syndrome and mental health, the hospital reality - particularly in ICUs - has been a cause for the professional stress of workers, which may evolve to Burnout Syndrome (BS) ${ }^{(3)}$, defined as syndrome psychological related to service provision and due to chronic emotional overload at work. Vulnerability to development increases when it involves a significant burden of responsibility, protection and care for others ${ }^{(5)}$.

Professional activities directly linked to patients have been considered to trigger BS. Thus, professionals such as nursing technicians, who perform their activities at the bedside, are more vulnerable $^{(2)}$. Clinical manifestations of BS can involve physical, psychological, behavioral and defensive symptoms, such as fatigue, sleep and/or appetite disorders, muscle pain, anxiety, frustration, irritability, difficulty concentrating, tendency to isolation, among others $^{(6-7)}$. The translation of the word Burnout summarizes how exhausted professionals feel: "being consumed by fire"(8).

As a consequence, workers who suffer from BS are demotivated at work, are absent regularly, do their tasks as little as possible, leave early and resign ${ }^{(9)}$.Both absenteeism and the reduction in the number of workers can compromise the care provided. In this context, too, nursing professionals may suffer from high levels of stress, workload, inadequate work environment and professional dissatisfaction, which can compromise patient safety ${ }^{(10)}$.

Among the instruments used to verify BS occurrence, currently the most used by the international scientific community is the one developed by Christina Maslach and Susan Jackson. The scale is made up of personal, social and institutional variables. The factors that define BS standard are ${ }^{(8)}$ : a) Emotional exhaustion (EE): lack of energy/enthusiasm and feeling depleted of resources. Here, it is possible to identify feelings of tension, frustration and lack of energy; b) Depersonalization (DP): when professionals start to treat co-workers, clients and the organization as objects. There may be emotional instability; c) Personal accomplishment (PA): related to the tendency of workers to negatively assess themselves. There is dissatisfaction and unhappiness with professional development.

In ICU practice, the influence of the environment on workers' health conditions, both physical and psychological, is perceived. The consequences of BS can affect not only individuals, but also co-workers. Research on workers' health in Brazil has gained significant space, since, for adequate, safe and qualified assistance, it is necessary that workers are satisfied and in conditions to perform their work properly. However, there are still few studies that consider BS prevalence specifically in nursing technicians, a share that makes up $57.3 \%$ of the total nursing professionals in Brazil ${ }^{(11)}$.

Knowing BS prevalence in nursing technicians who work at ICU can support strategies and interventions directed at work conditions and organization, as well as social relationships, constituting important tools for people management and workers' health.

\section{OBJECTIVE}

To verify Burnout Syndrome prevalence among nursing technicians of an adult Intensive Care Unit, to associate prevalence with sociodemographic and clinical data.

\section{METHOD}

\section{Ethical aspects}

This study followed the Regulatory Guidelines and Norms for Research involving Human Beings, Resolution 466 of $2012^{(12)}$. It was approved by the institution's Ethics and Research Committee. All participants signed an Informed Consent Form.

\section{Design, place of study, and period}

This is a cross-sectional study, designed according to the Protocol Strengthening the Reporting of Observational Studies in Epidemiology (STROBE) ${ }^{(13)}$. Data collection took place between the months of March to April 2018, in an ICU of complexity level III, with 59 beds, 100\% focused on serving users of the Unified Health System (SUS - Sistema Único de Saúde).

\section{Population or sample; inclusion and exclusion criteria}

To calculate the sample, an estimated population of 209 nursing technicians was considered, expected prevalence of $9 \%$, absolute error margin of $5 \%$ and confidence level of $95 \%$. The sample was defined by 117 employees, with a $10 \%$ increase for eventual losses or refusals.

Nursing technicians aged 18 years or over, of both sexes, who performed at least 20 daily hours per day of care at ICU and were exercising their functions during the collection period were included.

Workers on vacation, on medical leave, on maternity leave and who were new to the sector were excluded (less than three months).

\section{Study protocol}

Data related to BS were collected through the application of the Human Services Survey - Maslach Burnout Inventory (MBI) scale, in its version validated for Brazilian Portuguese, intended for professionals whose work has an assistance character. This scale consists of 22 items, divided into three subscales: EE (nine items), DP (five items), and PA (eight items) ${ }^{(14)}$. Each item is accompanied by a response scale, from 0 to 6 points, which measures the frequency of feelings related to the syndrome $(0=$ never; $1=$ sometimes a year; 2=once a month or less; 3 =sometimes per month; 4=once a week; $5=$ a few times a week; $6=$ daily ${ }^{(8)}$.For the scale score, each dimension is divided into three levels (high, moderate, and low). For EE, a high-level score of 27 or more is considered; moderate, from 19 to 26 points; low level, with 19 points or less. For DP, a high score of 10 or more is considered; moderate, 6 to 9 points; low level, less than 6 points. PA has the opposite direction to the other subscales: considered a high level between 0 and 33 points; moderate, from 34 to 39 points; low level, equal to or above 40 points ${ }^{(8)}$.

The instrument used in data collection was self-applied and provided in the work environment, leaving participants to choose the best place to answer it, in order to provide an environment in which they felt comfortable, since the MBI contains personal information. 
Due to the lack of consensus in the literature for the diagnosis and also to the risk of underestimating the BS rate of individuals who present only one of the unbalanced dimensions, in this study, two criteria were used to verify BS:a) The first and most conservative, according to the guidelines of Maslach et al. ${ }^{(15)}$, considers for the diagnosis simultaneously a high score in EE and DP dimensions and a low score in the PA dimension, i.e., changes in the three dimensions; b) The second, according to Grunfeld et al. ${ }^{(16)}$, considers a high score in at least one of the dimensions (EE or DP), or a low score in PA, i.e., changes in at least one of the dimensions.

\section{Analysis of results, and statistics}

For statistical analysis, Statistical Package for the Social Sciences version 21.0 was used. Continuous variables were expressed as mean and standard deviation or median and interquartile range. Categorical variables were expressed as percentages and relative frequencies. To compare means, Student's t test was used. In case of asymmetry, Mann-Whitney test was applied. Associations were performed using Pearson's chi-square test or Fisher's exact test. A two-tailed p value less than 0.05 was considered significant.

\section{RESULTS}

\section{Sociodemographic and clinical characteristics of the sample}

Thus, 209 potentially eligible nursing technicians were selected. Of these, 47 were excluded by at least one of the exclusion criteria, 34 did not return the questionnaire and six did not accept to participate. At the end, 122 nursing technicians were included. To calculate BS prevalence, 117 nursing technicians were considered, according to the criteria of Maslach et al. ${ }^{(15)}$ and 116 according to the criteria of Grunfeld et al. ${ }^{(16)}$, due to failure to complete some $\mathrm{MBI}$ questionnaires in their entirety.

Table 1 shows participants' sociodemographic and clinical characteristics.

Table1 -Sociodemographic and clinical characteristics of the interviewed workers, Porto Alegre, Rio Grande do Sul, Brazil, 2018

\begin{tabular}{|c|c|}
\hline Variables & $n=122$ \\
\hline Age (years)* & $39 \pm 2.5$ \\
\hline Female $(\%)^{\dagger}$ & $92(76)$ \\
\hline With a companion $(\%)^{+}$ & $79(72.5)$ \\
\hline With children $(\%)^{\dagger}$ & $87(72)$ \\
\hline Withreligion (\%) ${ }^{\dagger}$ & $101(84)$ \\
\hline Family income (minimum wages)* & $6.3 \pm 2.2$ \\
\hline \multicolumn{2}{|l|}{ Years of study $(\%)^{\dagger}$} \\
\hline $\begin{array}{l}13 \text { to } 16 \\
16 \text { and more }\end{array}$ & $\begin{array}{l}98(80) \\
24(20)\end{array}$ \\
\hline Completing higher education $(\%)^{\dagger}$ & $29(24)$ \\
\hline Possui another job $(\%)^{+}$ & $16(13)$ \\
\hline Professional career span (years)* & $13.6 \pm 6.3$ \\
\hline Professional career spanat ICU (years)* & $8.7 \pm 6$ \\
\hline Total weekly hours worked* & $40 \pm 17.7$ \\
\hline Comorbidities $(\%)^{\dagger}$ & $55(45.5)$ \\
\hline Sedentary lifestyle & $62(52)$ \\
\hline Depression & $15(12)$ \\
\hline Hypertension & $13(11)$ \\
\hline Smoking & $9(7)$ \\
\hline Anxiety & $2(1.7)$ \\
\hline Bipolarity & $2(1.7)$ \\
\hline
\end{tabular}

\section{Human Services Survey scores among workers}

Table 2 shows the data related to MBI application and the levels of each dimension.

Table 2 -Distribution of the threeHuman Services Survey dimensions with the respective percentages among the workers interviewed, Porto Alegre, Rio Grande do Sul, Brazil, 2018

\begin{tabular}{lc}
\hline Variables & $\mathbf{n}(\%)$ \\
\hline Emotional exhaustion (EE) & \\
$\quad$ High & $61(52.6)$ \\
Moderate & $30(25.9)$ \\
Low & $25(21.6)$ \\
Depersonalization (DP) & \\
$\quad$ High & $47(40.9)$ \\
Moderate & $51(44.3)$ \\
Low & $17(14.8)$ \\
Personal accomplishment (PA) & \\
High & $10(8.5)$ \\
Moderate & $16(13.7)$ \\
Low & $91(77.8)$ \\
Burnout Syndrome & \\
Maslach et al. & \\
$\quad$ Grunfeld et al. ${ }^{(16)}$ & $23(19.7)$ \\
\hline
\end{tabular}

In $\mathrm{EE}$, just over half of participants had a high score (52.6\%). In DP, most of them presented scores at a moderate level (44.3\%). In PA, most scored low (77.8\%).

BS prevalence in the studied sample was 19.7\%, 23 individuals, according to the criteria established by Maslach et al. ${ }^{(15)}$, and $62.9 \%$, 73 individuals, using the criteria proposed by Grunfeld et al. ${ }^{(16)}$.

\section{Association between Burnout Syndrome, sociodemographic and clinical data of the sample, according to the criteria proposed by Maslach et al. ${ }^{(15)}$}

The associations between the sociodemographic and clinical data of the sample and BS, according to the criteria proposed by Maslach et al. ${ }^{(15)}$, are described in Table 3, which shows that there was no significant association between variables.

Table 3 -Association between sociodemographic and clinical data of the sample and Burnout Syndrome, according to Maslach et al..(15), Porto Alegre, Rio Grande do Sul, Brazil, 2018

\begin{tabular}{|c|c|c|c|}
\hline Variables & $\begin{array}{c}\text { With } \\
\text { Burnout } \\
\text { Syndrome } \\
(n=23)\end{array}$ & $\begin{array}{c}\text { Without } \\
\text { Burnout } \\
\text { Syndrome } \\
(n=94)\end{array}$ & $p$ \\
\hline Professional career span (years)* & $13.4 \pm 6.4$ & $13.6 \pm 5.6$ & 0.900 \\
\hline Professional career spanat ICU (months) & $108[57-147]$ & $96[60-144]$ & 0.491 \\
\hline Family income (minimum wages)* & $6.6 \pm 2.3$ & $5.1 \pm 1.7$ & 0.005 \\
\hline Total weekly hours worked* & $40.2 \pm 19.0$ & $37.6 \pm 7.5$ & 0.509 \\
\hline Another job & $2(13.3)$ & $13(86.7)$ & 0.755 \\
\hline${\text { Completing higher education }(\%)^{+}}^{+}$ & $5(17.9)$ & $23(82.1)$ & 0.998 \\
\hline Religion $(\%)^{\dagger}$ & $19(19.4)$ & $79(80.6)$ & 0.754 \\
\hline Comorbidities $(\%)^{\dagger}$ & $14(60.9)$ & $37(39.4)$ & 0.103 \\
\hline Smoking $(\%)^{+}$ & $4(17.4)$ & $5(5.3)$ & 0.073 \\
\hline Depression $(\%)^{\dagger}$ & $4(17.4)$ & $10(10.6)$ & 0.471 \\
\hline Bipolarity $(\%)^{+}$ & $0(0.0)$ & $2(2.1)$ & 1.000 \\
\hline Anxiety $(\%)^{\dagger}$ & $1(4.3)$ & $1(1.1)$ & 0.356 \\
\hline Sedentary lifestyle $(\%)^{\dagger}$ & $10(43.5)$ & $52(55.3)$ & 0.431 \\
\hline
\end{tabular}

Note: *Continuous variables expressed as mean \pm standard deviation; ${ }^{+}$categorical variables expressed as $n(\%) ;{ }^{\ddagger}$ asymmetric variables presented as median and interquartile range. 
Association between Burnout Syndrome, sociodemographic and clinical data of the sample, according to the criteria proposed by Grunfeld et al. ${ }^{(16)}$

The associations between the sociodemographic and clinical data of the sample and BS, according to the criteria of Grunfeld et al. ${ }^{(14)}$, are described in Table 4, which shows a statistically significant association between BS and comorbidities $(p=0.033)$ and between BS and depression ( $p=0.004)$.

Table 4 -Association between sociodemographic and clinical data of the sample and Burnout Syndrome, according to Grunfeld et al. ${ }^{(16)}$, Porto Alegre, Rio Grande do Sul, Brazil, 2018

\begin{tabular}{|c|c|c|c|}
\hline Variables & $\begin{array}{c}\text { With } \\
\text { Burnout } \\
\text { Syndrome } \\
(n=73)\end{array}$ & $\begin{array}{c}\text { Without } \\
\text { Burnout } \\
\text { Syndrome } \\
(n=43)\end{array}$ & $p$ \\
\hline Professional career span* & $14.5 \pm 7.1$ & $13.3 \pm 5.9$ & 0.330 \\
\hline Professional career spanat ICUキ & 96 [51 - 144] & $96[60-156]$ & 0.730 \\
\hline Family income (minimum wages)* & $6.5 \pm 2.2$ & $6.1 \pm 2.2$ & 0.397 \\
\hline Total weekly hours worked* & $41.0 \pm 25.5$ & $39.8 \pm 11.8$ & 0.729 \\
\hline Another job(\%) ${ }^{\dagger}$ & $12(16.4)$ & $4(9.3)$ & 0.425 \\
\hline Completing higher education(\%) ${ }^{\dagger}$ & $18(24.7)$ & $11(25.6)$ & 1.000 \\
\hline Religion(\%) ${ }^{\dagger}$ & $59(80.8)$ & $38(90.5)$ & 0.269 \\
\hline Comorbidities(\%) ${ }^{\dagger}$ & $40(54.8)$ & $14(32.6)$ & 0.033 \\
\hline Smoking $(\%)^{\dagger}$ & $7(9.6)$ & $2(4.7)$ & 0.481 \\
\hline Depression $(\%)^{\dagger}$ & $15(20.5)$ & $0(0.0)$ & 0.004 \\
\hline Bipolarity $(\%)^{+}$ & $2(2.7)$ & $0(0.0)$ & 0.529 \\
\hline Anxiety $(\%)^{\dagger}$ & $2(2.7)$ & $0(0.0)$ & 0.529 \\
\hline Sedentary lifestyle $(\%)^{\dagger}$ & $38(52.8)$ & $19(44.2)$ & 0.485 \\
\hline
\end{tabular}

\section{DISCUSSION}

This study sought to identify BSprevalence in nursing technicians in an adult ICU of a large public hospital in southern Brazil, correlating it with sociodemographic and clinical data. As there is no consensus regarding the diagnosis and in order to avoid measurement bias, BS prevalence was calculated according to the more conservative criteria of Maslach et al. ${ }^{(15)}$ ( 23 cases=19.7\%) and also according to the criteria of Grunfeld et al. ${ }^{(16)}$ (73 cases=62.9\%). Although distinct, both deserve attention, as they lead to reflection and better understanding about the health situation of these workers. Adopting a less conservative criterion for the diagnosis of BS, in addition to having a higher prevalence, also revealed a statistically significant association when compared to the presence of comorbidities and depression.

The sociodemographic characteristics presented are similar to those of other studies ${ }^{(17-19)}$ that assessed BS in nursing professionals, in which the mean age of participants is close to 40 years, the female sex predominates and most live with a partner. The fact that nursing is a predominantly female profession ${ }^{(11)}$ must be considered, as stress and $\mathrm{BS}$ are predominant in women, since they expose their feelings more ${ }^{(10)}$.

When it comes to BS prevalence, the data found in the literature are heterogeneous, varying according to the professional category and the method used to assess it; this makes comparison between studies difficult. Furthermore, the professional category composed of nursing technicians is present in the Brazilian health care network, not being provided for, regulated and, therefore, existing abroad. Even so, in the national scenario, most of the findings in the literature refer to the nursing staff as a whole, considering nurses and nursing technicians ${ }^{(2,10,17-19)}$.Few studies specifically consider BS of nursing technicians ${ }^{(20-21)}$, although the specificity of their attributions is known, since they develop a more direct and continuous degree of interaction with patients, as they are practically all the time on the edge of the bed, which generates greater vulnerability to develop $\mathrm{BS}^{(2)}$.

A cross-sectional study conducted with 50 nursing professionals (27 technicians, 7 assistants and 16 nurses) working at ICU and Semi-Intensive Care Unit of a university hospital in São Paulo showed a prevalence of $12 \%$ of BS among participants. Of these, about $66 \%$ were nursing technicians, indicating BS predominance in this professional category ${ }^{(19)}$.

High BS prevalence presented in the present study is corroborated by results previously presented in a Brazilian observational study ${ }^{(22)}$, conducted with 130 general and cardiac ICU nursing professionals from two large hospitals in Rio de Janeiro, which demonstrated BS prevalence of $55.3 \%$.The findings showed that more than a third of workers had high EE (37.7\%), in addition to the inverse association between this variable and work performance ${ }^{(22)}$. It should also be noted that there was no discrimination by the authors between the different professional categories (nurses, technicians and nursing assistants) (22).

The above findings show the susceptibility to BS development in professionals who works at ICU, particularly nursing technicians, for being at the bedside, and directly exposed to emotionally intense situations such as illness, death and family ${ }^{(1-3)}$.

In relation to the subscale score, in the studied sample, high levels of EE were found in $52.6 \%$ of individuals. Similar results were evidenced in a cross-sectional study with 502 nursing professionals working at ICU, with $54.4 \%$ of the sample consisting of nursing technicians ${ }^{(23)}$, in which $57 \%$ of day shift workers had high EE. The scientific literature indicates that $\mathrm{EE}$ can be considered an initial factor in BS, since workload, the characteristics of the environment and the interpersonal demands of the worker are items considered in this subscale ${ }^{(19)}$.In fact, a recent publication presented data obtained from professionals from 40 institutions in São Paulo, revealing that EE was more intense in nurses who worked in institutions that had the worst working conditions regarding autonomy over the environment. ${ }^{(24)}$.

Our findings also indicated DP in $40.9 \%$ of nursing technicians, a percentage similar to that found in a study with 50 nursing professionals (54\% of the sample composed of technicians), ICU and Semi-Intensive Unit (44\%) workers ${ }^{(19)}$. It is known that DP is generally represented by attitudes that involve withdrawal and harsh treatment to individuals, as a way to mitigate exhaustion ${ }^{(19)}$. In Spanish research, with 140 nurses who worked in different sectors of a hospital, DP levels were associated with uncertainty regarding patient treatment, inadequate preparation of professionals and problems among the nursing staff(25).

In our study, a low PA level was found in $77.8 \%$ of the sample. Findings from a cross-sectional study ${ }^{(23)}$, carried out in Paraná State, corroborate the data presented. The authors showed that nursing assistants and technicians are more likely to have a low PA when compared to other members of the health staff ${ }^{(23)}$. Despite the importance of their work, they have less autonomy in relation to other professionals, are little recognized and valued, which can generate feelings of worthlessness and incompetence ${ }^{(23)}$.

In the present study, when considering the criteria of Grunfeld et al. ${ }^{(16)}$, there was a statistically significant association between BS and 
depression. Recently, a Brazilian study carried out with 72 nursing professionals working in four ICUs in three different hospitals, $95.8 \%$ of the sample consisting of technicians and the rest by assistants, showed a suggestive picture of depression in $11.1 \%$ of participants ${ }^{(20)}$. This relationship had also been described in a previous study, carried out in São Paulo, in 2011, with 67 ICU nursing workers (66\% of the sample composed of technicians), in which a prevalence of $28.4 \%$ of depression was evidenced, $8.4 \%$ of the sample had sufficient scores for depression or severe depression. There was no stratification regarding the professional category, i.e., this percentage involves not only nursing technicians, but also nurses. Differing from the results presented, the authors showed a statistically significant association between depression and marital status $(\mathrm{OR}=1.5)$, night work $(\mathrm{OR}=1.4)$, and double working hours $(\mathrm{OR}=2.1)^{(26)}$.

The above considerations lead to reflections regarding the proximity between BS and depression among nursing technicians. Although depressive conditions can occur as a manifestation of BS, they are different constructs, although they have common aspects ${ }^{(27)}$. Thus, BS should receive as much attention as any other psychological disorder. In an integrative review, in which ten articles were included, it was pointed out that high BS rate in nursing professionals has been receiving more and more focus in the health sector and many times individuals have comorbidities associated with psychiatric disorders such as depression. The authors stressed that it is necessary to assess the relationship between these disorders and aspects related to company (hours worked, working conditions, conflicts, turnover), individuals (physical, mental, family) and/or professionals (accomplishment, productivity) ${ }^{(28)}$.

The findings of this study also demonstrated a significant association between BS and comorbidities. It is known that a higher level of stress at work can adversely affect the physical and psychological health of nursing workers ${ }^{(29-30)}$. The high proportion of sedentary workers in this sample is similar to that presented in a cross-sectional study conducted with 502 nursing workers from a philanthropic hospital, 273 (54.4\%) of whom were technicians. Most of the employees on the day shift were sedentary, and this factor was associated with high DP and low $P A^{(23)}$.In this regard, it is known that physical activity should be encouraged, since it results in benefits on health professionals' mental health. In addition to providing mental energy, it helps to reduce work fatigue due to the release of neurotransmitters, causing a feeling of well-being. Moreover, physical activity is recommended as a protective factor for several chronic diseases ${ }^{(31)}$.

As for strategies to cope with BS, a recent Brazilian integrative review showed three different possible axes of actions taken by health institutions with the aim of reducing stress among the nursing staff: management and education, dialogue and reflections of work, and spaces for biopsychosocial and physical well-being. It is necessary that the development and implementation of strategies are carried out considering the suggestion of the professionals involved in the processes, so that they feel valued and so that it is possible to make everyday life more productive ${ }^{(32)}$.

Either through changes in the environment in order to make it more suitable and favorable, or through efforts aimed at increasing motivation and improving workers' mental health, occupational stress prevention is essential to promote better results, both for patients and for professionals and institutions.

\section{Study limitations}

A possible limitation of the study was the failure to complete some questionnaires in their entirety and the non-return of some instruments by participants. Another possible obstacle is related to the cross-sectional design, which is limited to punctually analyzing professionals' characteristics in a short period of time, not being able to establish cause and effect relationships.

\section{Contributions to nursing, health, and public policies}

Studies like this can assist nursing managers in planning actions aimed at these professionals, in order to mobilize resources and proposals for improvements that favor a better perception of selfesteem among these professionals and a more positive perception related to the work environment. Acting directly on factors associated with exhaustion will allow health managers to prevent BS from spreading among their workers.

\section{CONCLUSION}

BS prevalence among the nursing technicians assessed - regardless of the method used for measurement - should be considered. In the sample, high levels of EE, moderate levels of DP and low PA were evidenced, which denotes the exposure of these workers to factors that determine stress.

In addition to these findings, a statistically significant association was found between BS and depression, and also between BS and comorbidities, allowing us to infer that the level of stress at work can result in damage to workers' physical and psychological health.

BS is a very broad topic, although there is still room for further investigation specifically considering the technical nursing professional, due to the direct and constant attention to the main needs of patients. Based on studies like this, it is expected to envision alternatives that make these professionals less stressful professional practice.

Prevention strategies related to habits and lifestyles should be encouraged and promoted, especially with regard to physical inactivity and alcohol consumption, aiming to modify the profile of morbidity and modifiable risk factors related to chronic non-communicable diseases in the population studied.

\section{REFERENCES}

1. Dorigan GH, Guirardello EB. Effect of the practice environment of nurses on job outcomes and safety climate. Rev Latino-Am Enfermagem. 2018;26:e3056. doi: 10.1590/1518-8345.2633.3056

2. Guirardello EB. Impact of critical care environment on burnout, perceived quality of care and safety attitude of the nursing team. Rev Latino-Am Enfermagem. 2017;25:e2884. doi: 10.1590/1518-8345.1472.2884 
3. Chuang CH, Tseng PC, Lin CY, Lin KH, Chen YY. Burnout in the intensive care unit professionals: A systematic review. Medicine (Baltimore). 2016;95(50):e5629. doi: 10.1097/MD.0000000000005629

4. Santos LC, Cavalcanti EO, Ataídes JS, Silva DT. Fatores predisponentes à síndrome de burnout e estresse em enfermeiros na unidade de terapia intensiva. REFACI [Internet].2018 [cited 2020 Jun 24];2(2):1-12.Available from: http://revista.faciplac.edu.br/index.php/REFACl/article/ view/578/213

5. Tironi MOS, Teles JMM, Barros DDS, Vieira DFVB, Silva Filho CMD, et al. Prevalência de síndrome de burnout em médicos intensivistas de cinco capitais brasileiras. Rev Bras Ter Intensiva. 2016;28(3):270-77.doi: 10.5935/0103-507X.20160053

6. Vasconcelos EM, Martino MMF, França SPS. Burnout and depressive symptoms in intensive care nurses: relationship analysis. Rev Bras Enferm. 2018;71(1):135-41. doi: 10.1590/0034-7167-2016-0019

7. Santos JS, Santos LBP, Lima JR. Síndrome de Burnout em enfermeiros de Unidade de Terapia Intensiva: produção científica de Enfermagem. Rev Dest Acad. 2018;10(3). doi: 10.22410/issn.2176-3070.v10i3a2018.1960

8. Maslach C, Jackson SE. The measurement of experienced burnout. J Occup Behav [Internet]. 1981 [cited 2019 Oct 15];2:99-113. Available from:https://smlr.rutgers.edu/sites/default/files/documents/faculty_staff_docs/TheMeasurementofExperiencedBurnout.pdf.

9. Carlotto M. A relação profissional-paciente e a síndrome de Burnout. Encontro: Rev Psicol [Internet]. 2010 [cited 2020 Jun 25];12(17):7-20. Available from: https://revista.pgsskroton.com/index.php/renc/article/view/2543

10. Padilha KG, Barbosa RL, Andolhe R, Oliveira EM, Ducci AJ, Bregalda RS, et al. Carga de trabalho de enfermagem, estresse/burnout, satisfação e incidentes em unidade de terapia intensiva de trauma. Texto Contexto Enferm. 2017;26(3):e1720016. doi: 10.1590/0104-07072017001720016

11. Conselho Federal de Enfermagem - COFEN. Enfermagem em Números [Internet]. Brasil; 2020 Jun 26 [cited 2020 May 01]. Available from: https://www.cofen.gov.br/enfermagem-em-numeros.

12. Conselho Nacional de Saúde (BR). Resolução n 466, de 12 de dezembro de 2012. Brasília: DF, 2012.

13. Von Elm E, Altman DG, Egger M, Pocock SJ, Gotzsche PC, Vandenbroucke JP. The Strengthening the Reporting of Observational Studies in Epidemiology (STROBE) Statement: guidelines for reporting observational studies.J Clin Epidemiol. 2008;61(4):344-9. doi: 10.1016/j. jclinepi.2007.11.008

14. Carlotto M, Camara S. Propriedades psicométricas do Maslach Burnout Inventory em uma amostra multifuncional. Estud Psicol. 2007;24(3):325-332. doi: 10.1590/S0103-166X2007000300004

15. Maslach C, Schaufeli WB, Leiter MP. Job Burnout. Ann Rev Psychol. 2001;52(1):397-422. doi: 10.1146/annurey.psych.52.1.397

16. Grunfeld E, Whelan TJ, Zitzelsberger L, Willan AR, Montesanto B, Evans WK. Cancer care workers in Ontario: prevalence of burnout, job stress and job satisfaction. CMAJ [Internet]. 2000 [cited 2019 Oct 15];163(2):166-9. Available from: https://www.ncbi.nlm.nih.gov/pmc/articles/ PMC80206/

17. Nascimento JOV, Santos J, Meira KC, Pierin AMG, Souza-Talarico JN. Trabalho em turnos de profissionais de enfermagem e a pressão arterial, burnout e transtornos mentais comuns. Rev Esc Enferm USP. 2019;53:e03443. doi: 10.1590/s1980-220x2018002103443

18. Baldonedo-Mosteiro M, Almeida MCS, Baptista PCP, Sánchez-Zaballos M, Rodriguez-Diaz FJ, Mosteiro-Diaz MP. Burnout syndrome in Brazilian and Spanish nursing workers. Rev Latino-Am Enfermagem. 2019;27:e3192. doi: 10.1590/1518-8345.2818.3192

19. Silva GSA, Silva GAV, Silva RM, Andolhe R, Padilha KG, Costa ALS. Estresse e burnout em profissionais de enfermagem de unidade de terapia intensiva e semi-intensiva. Rev Cient Sena Aires [Internet]. 2018 [cited 2020 Jun 22];7(1):5-11. Available from: http://revistafacesa.senaaires. com.br/index.php/revisa/article/view/297

20. Moura RS, Saraiva FJC, Santos RM, Rocha KRS, Silva NAR, Albuquerque WDM. Estrés, burnout y depresión em los profesionales de enfermería de las unidades de cuidados intensivos. Enferm Glob. 2019;18(2):79-123. doi: 10.6018/eglobal.18.2.337321

21. Ferreira NN, Lucca SR. Síndrome de burnout em técnicos em enfermagem de um hospital público do Estado de São Paulo. Rev Bras Epidemiol. 2015;18(1):68-79. doi: 10.1590/1980-5497201500010006

22. Silva JLL, Teixeira LR, Soares RS, Costa FS, Aranha JS, Teixeira ER. Estrés y factores psicosociales em el trabajo de enfermeiros intensivistas. Enferm Glob. 2017;16(48):80-120. doi: 10.6018/eglobal.16.4.249321

23. Vidotti V, Ribeiro RP, Galdino MJQ, Martins JT. Burnout Syndrome and shift work among the nursing staff. Rev Latino-Am Enfermagem. 2018;26:e3022. doi: 10.1590/1518-8345.2550.3022

24. Nogueira LS, Sousa RMC, Guedes ES, Santos MA, Turrini RNT, Cruz DALM. Burnout and nursing work environment in public health institutions. Rev Bras Enferm. 2018;71(2):336-42. doi: 10.1590/0034-7167-2016-0524

25. Blanca-Gutiérrez JJ, Arias-Herrera A. Síndrome de burnout em personal de enfermería: asociación com estresoresdel entorno hospitalario, Andalucía, España. Enferm Univ. 2018;15(1):30-44.doi: 10.22201/eneo.23958421e.2018.1.62903

26. Vargas D, Dias APV. Prevalência de depressão em trabalhadores de enfermagem de Unidade de Terapia Intensiva: estudo em hospitais de uma cidade do noroeste do Estado São Paulo. Rev Latino-Am Enfermagem. 2011;19(5):[09 telas]. doi: 10.1590/S0104-11692011000500008

27. Quintas S, Queirós C, Marques A, Orvalho V. Os enfermeiros e a sua saúde no trabalho: a relação entre depressão e burnout. IJWC [Internet]. 2017 [cited 2019 Oct 15];13:1-20. Available from: http://ricot.com.pt/artigos/1/IJWC.13_SQuintas\%20et\%20al._1.20.pdf

28. Cunha AGG, Silva TMS, Santos ACC, Souza MLG. Síndrome de burnout em profissionais de enfermagem. Rev Saúde [Internet]. 2017 [cited 2020 Jun 23];11(1-esp). Available from: http://revistas.ung.br/index.php/saude/article/view/3168/2288 
29. Chen CH, Wang J, Yang CS, Fan JY. Nurse practitioner job content and stress effects on anxiety and depressive symptoms, and self-perceived health status. J Nurs Manag. 2016;24(5):695-704.doi: 10.1111/jonm.12375

30. Khamisa N, Peltzer K, llic D, Oldenburg B. Work related stress, burnout, job satisfaction and general health of nurses: a follow-up study. Int J Nurs Pract.2016;22(6):538-545. doi: 10.1111/ijn.12455

31. Vries JD, Claessens BJC, van Hooff MLM, Geurts SAE, van den Bossche SNJ, et al. Disentangling longitudinal relations between physical activity, work-related fatigue, and task demands. Int Arch Occup Environ Health. 2016;89(1):89-101. doi: 10.1007/s00420-015-1054-x

32. Calil TZN, Francisco CM. Estratégias nas instituições de saúde para reduzir estresse na enfermagem. RECIEN. 2020;10(29):40-7. doi: 10.24276/ rrecien2358-3088.2020.10.29.40-47 